\title{
$\mathrm{X}$ 線管 容器の漏洩線量について
}

\author{
金沢大学医学部付属病院中块放射線部 \\ 技師長 松 田憲 司 -山本 喜. 代治 \\ 金沢大学医学部付属診療 $\mathrm{X}$ 線技師学校 \\ 箱田外代治・前田秀夫・森美喜雄・渡辺清次
}

（論文受付 䀡和 34 年 4 月 5 日）

\section{THE STUDY ON THE LEAKAGE OF THE THERAPEUTIC X-RAY TUBES}

\author{
By Kenjt Matsuda \\ KIYOJI YAMAMOTO \\ Department of Radiology, Faculty of \\ Medicine, Kanazawa University. \\ TOYOJI HAKODA \\ Hideo MAEDA \\ MIKIO MORI \\ SEIJI WATANABE \\ School of for X-ray Technician, Faculty \\ of Medicine, Kanazawa University
}

(Article received : April 5, 1959)

\section{Summary}

The writers investigated the leakage from four kinds of therapeutic X-ray tubes now operating in the University Hospital of Kanazawa with following results.

The leaking dose was, in general, rather large. For example, it amounted to $440 \mathrm{mr}$. in hour at one meter under loading of $200 \mathrm{kVp} .25 \mathrm{~mA}$.

So the writers concluded that more strict control of X.ray apparatus should be employed in Japan.

\section{I. 緒 言}

放射線の許容量は 1950 年の国際放射線学会で $0.3 r / W$ と決められた が，現在ではさらに厳格な基準の設定が 要求され，てれよりはるかに少ない許容量2)を称える動 きが強い.わが国でも障害防止の見地から医療法施行規 則3)で防禦法を詳細に規定している．また，X線管容器 の利用線錐外の漏洩線量の検査規格も JIS ${ }^{4)}$ で定められ ているが，深部治療の装置では $170 \mathrm{kVp}$ で試験し，しか
も相対的な值で決められているので, 大電流装置に移行 しつつある現在，てれは罗当な方法と考えられない．わ れわれは現在使用中の㳭部治療装置 4 台について膤洩線 量を測定し，有意な值を得たのでその成績を報告する。

\section{II. 装置および測定器}

I. $\mathrm{KXC}-18$ 型

$200 \mathrm{kVp}-25 \mathrm{~mA}$ 振子照射装置

II. 信 愛 号

$200 \mathrm{kVp}-20 \mathrm{~mA}$

III. $\mathrm{KXC}-17$ 型 
IV. 信 愛 号 $200 \mathrm{kVp}-6 \mathrm{~mA}$

電離槽型サーベイ・メータ MI101B2 No. 200

\section{III. 測定方法}

測定条件は第 1 表のとおりで，われわれか治療に用い 第 1 表 各装置の測定条件

\begin{tabular}{c|cc|c|c}
\hline 装. 置 & 測 定 条 & $\begin{array}{c}\text { 線 } \\
\mathrm{r} / \mathrm{min}\end{array}$ & $\begin{array}{c}\text { 量 } \\
\mathrm{Cu}: \mathrm{mm}\end{array}$ \\
\hline I & $200 \mathrm{kVp}$ & $25 \mathrm{~mA}$ & 52.0 & 1.78 \\
II & $200 \mathrm{kVp}$ & $20 \mathrm{~mA}$ & 53.5 & 1.52 \\
II & $180 \mathrm{kVp}$ & $6 \mathrm{~mA}$ & 12.36 & 1.42 \\
IV & $180 \mathrm{kVp}$ & $6 \mathrm{~mA}$ & 13.6 & 1.20 \\
\hline
\end{tabular}

ている管電圧と管電流であり, 容器の高さは $1.25 \mathrm{~m}$ と しシャッターを閉じたまま，管軸を含む利用線錐の平 行断面と，直角断面の場合で，前者は放射口を床に対し て平行に, 後者は西直にした。

なお，第 1 図のように容器の表面では24,焦点より半径 $1 \mathrm{~m}$ の円周上では $22.5^{\circ}$ の間隔で 15 の測定点を定めた。

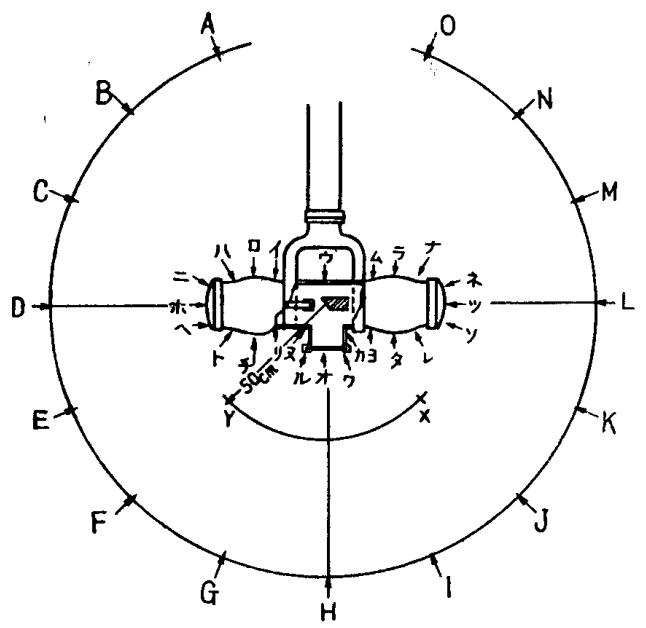

第1図装置の各测定点

管容器の漏洩を検べるには, 儧方よりの入射線の影響 をできるだけ少なくするように（1\%以下） $2.86 \mathrm{~mm} の$ 鉛板で写真 I.のように覆い，木製支持台に固定し，同時 に鉛遮晸简を除き， $1 \mathrm{~m}$ の各点で側方よりの影響を含め た線量もあわせて测定した。すた，瀮洩線線質を第 1 図 の $\mathrm{X}, \mathrm{Y}$ 点，放射口中心より $45^{\circ}$ ，焦点より $50 \mathrm{~cm} の$ 点 で半価層法により求めた。

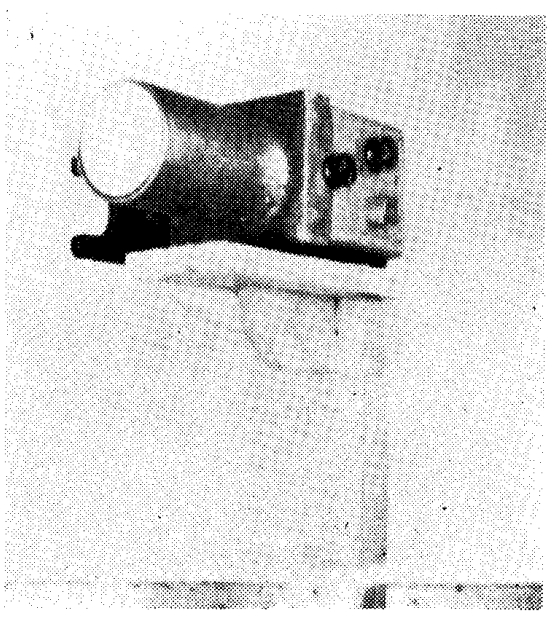

写真 I 電離槽型サーベィ・メータ

\section{IV. 測 定 成 績}

管容器表面の膤洩線量は第 2 表のごとくで，○印は放 射口の部分にあたり漏洩多量のため測定不能な点であり， 空欄は容器の機構上測定できなかった点である．各装置 とも测定点中央部才，ル，ワおよび陰極側にその漏洩量 が多くなっていた。第 3 表は $1 \mathrm{~m}$ の距離における測定值 を示し，上段は鉛板で遮蔽した值を，下段の括弧内は鉛 遮徶筒を除いた值で第 2 表とおなじく中央部 $\mathrm{H}, \mathrm{G}, \mathrm{I}$ お よび陰極側に多くなっている。なお，水平方向ではオの 点はいずれも漏洩量が多くなっており，また，第 II， II

第2表管容器表面の漏洩線量 単位- $\mathrm{mr}$ /時

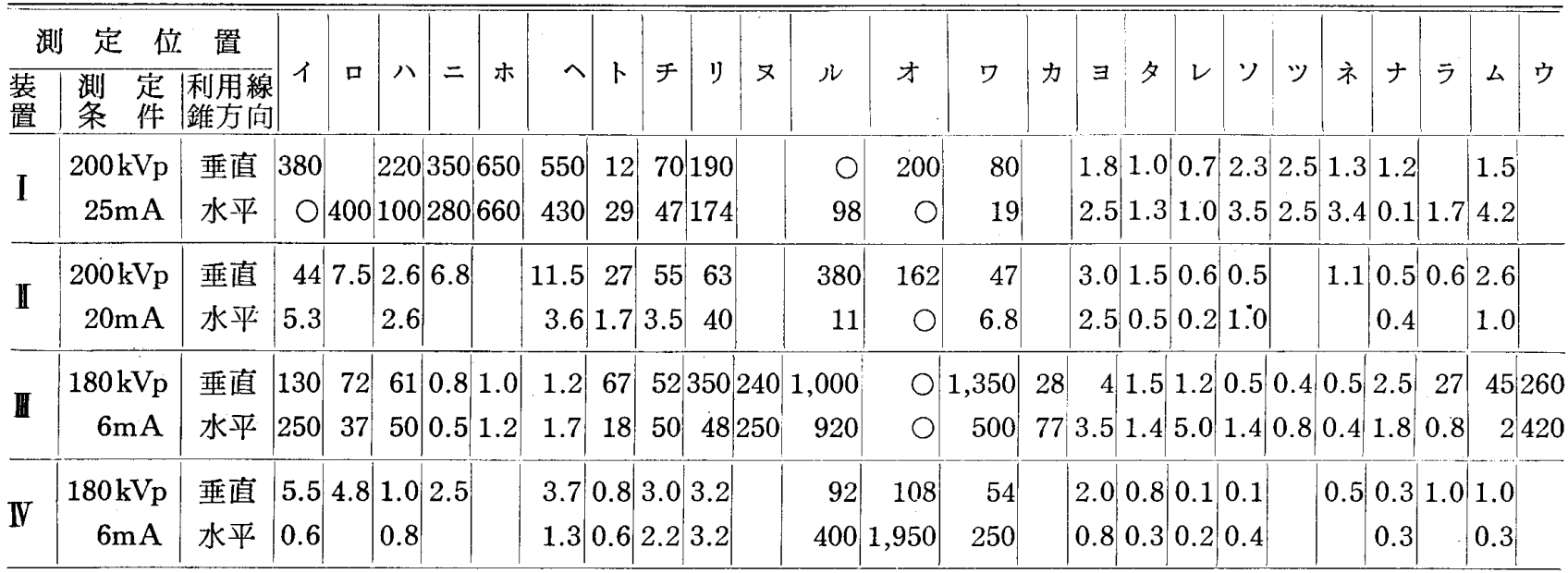

○印は測定不可能の点 
第3表 焦点測定器間 $1 \mathrm{~m}$ の漏洩楾量

単位: $\mathrm{mr}$ 時

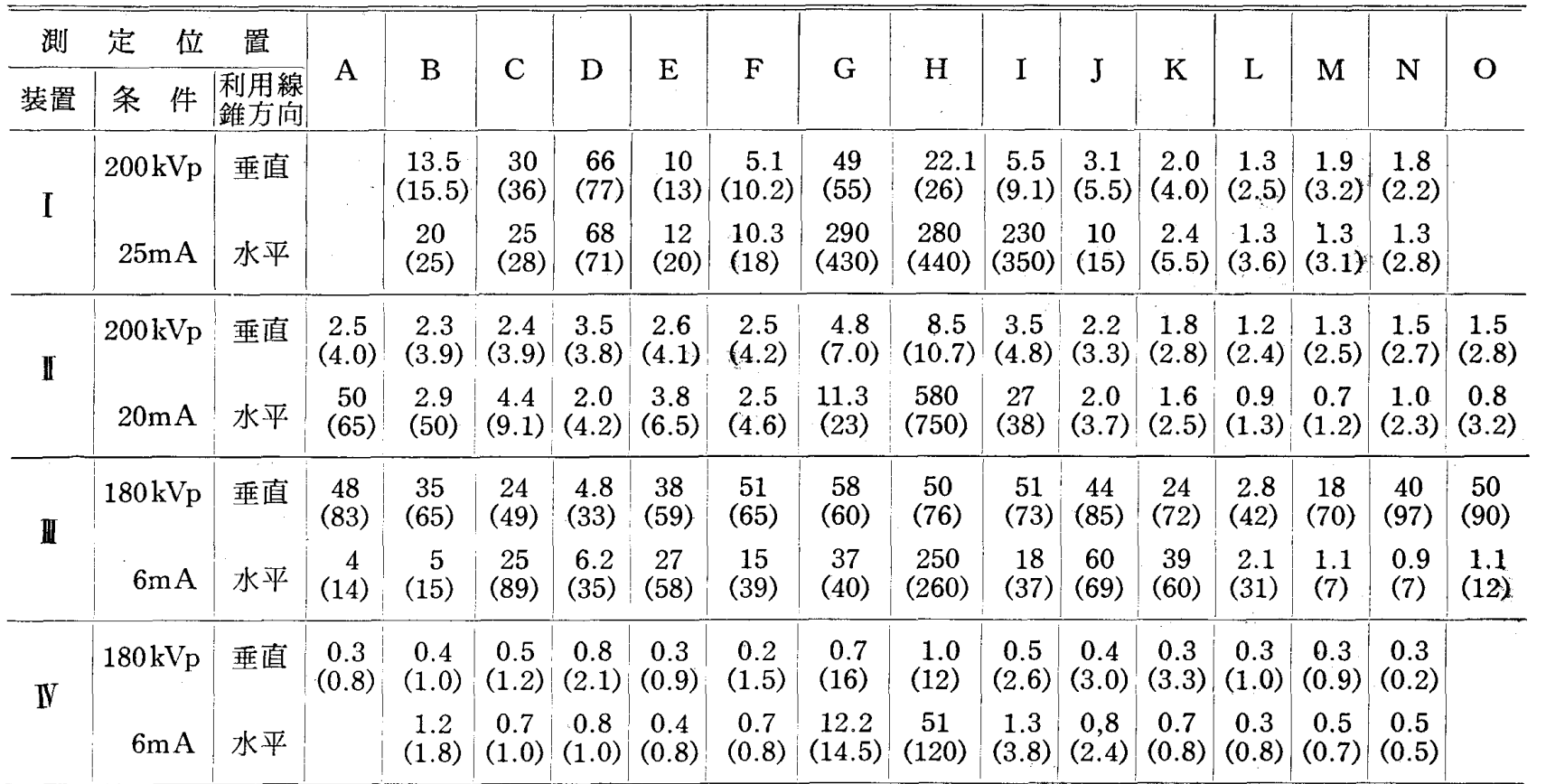

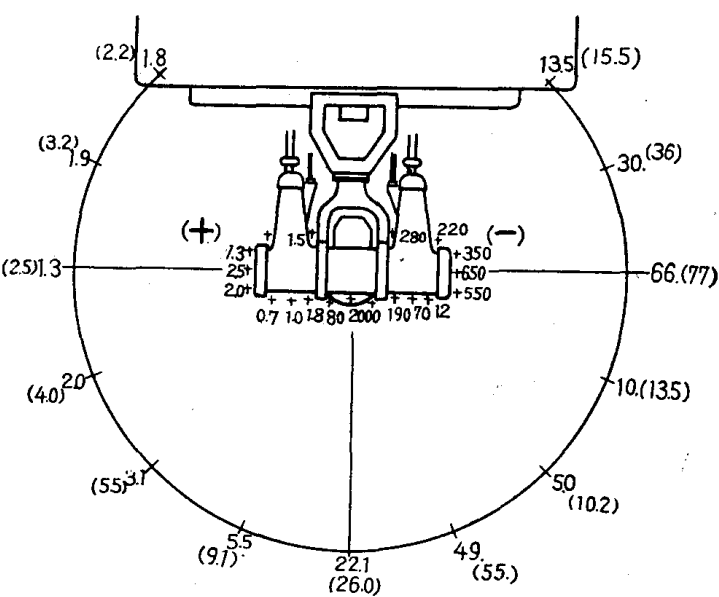

第 2 図 - 1

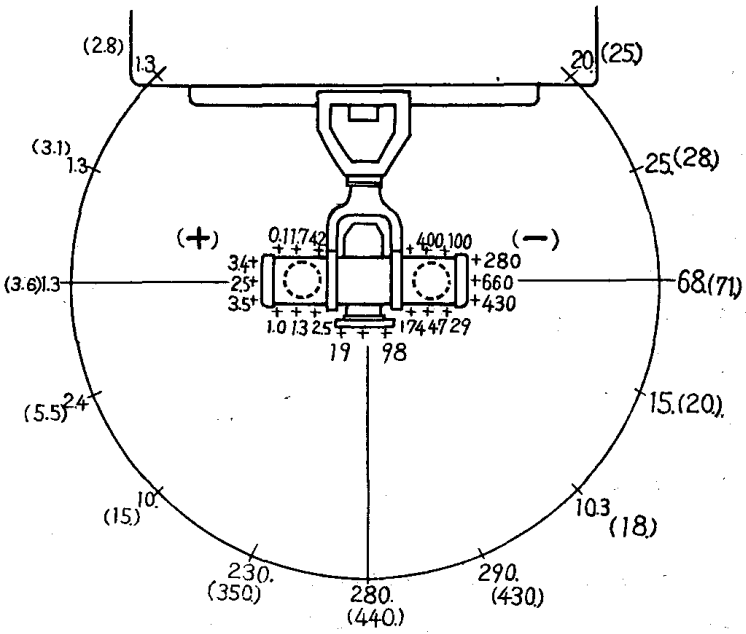

第 2 図 -2

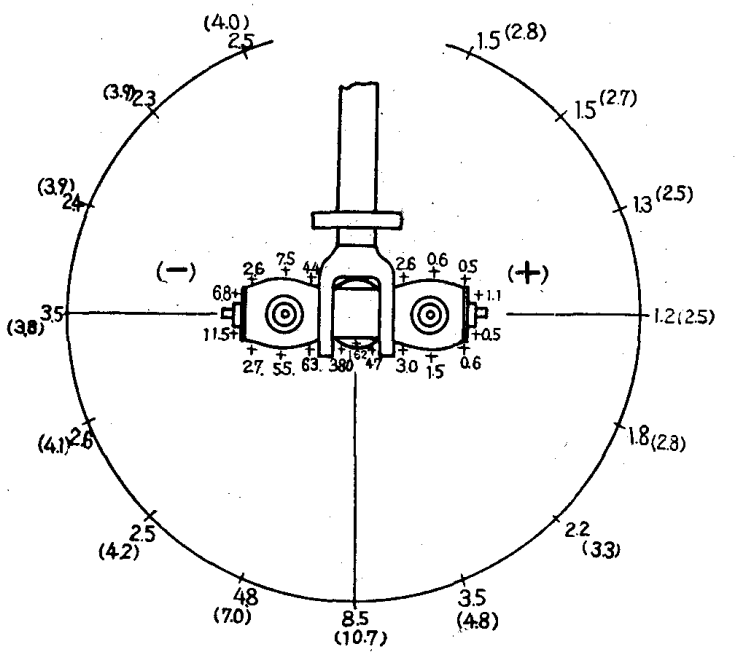

第 3 図 - 1

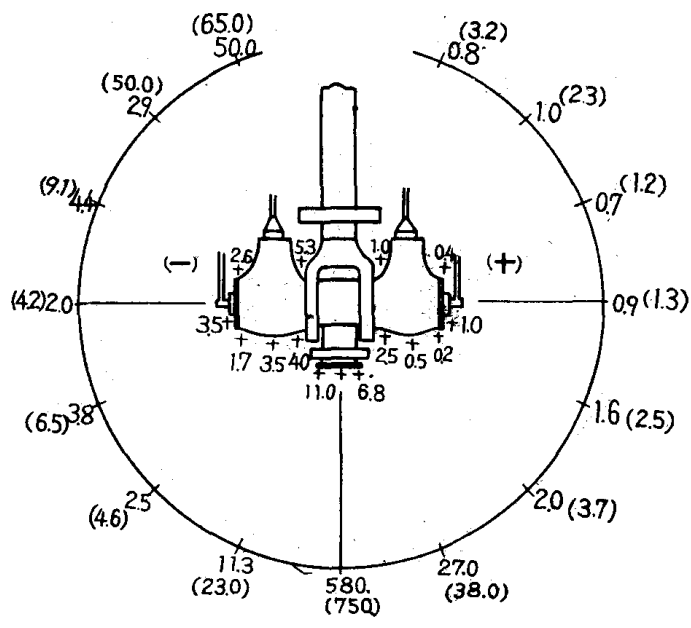

第 3 図 -2 


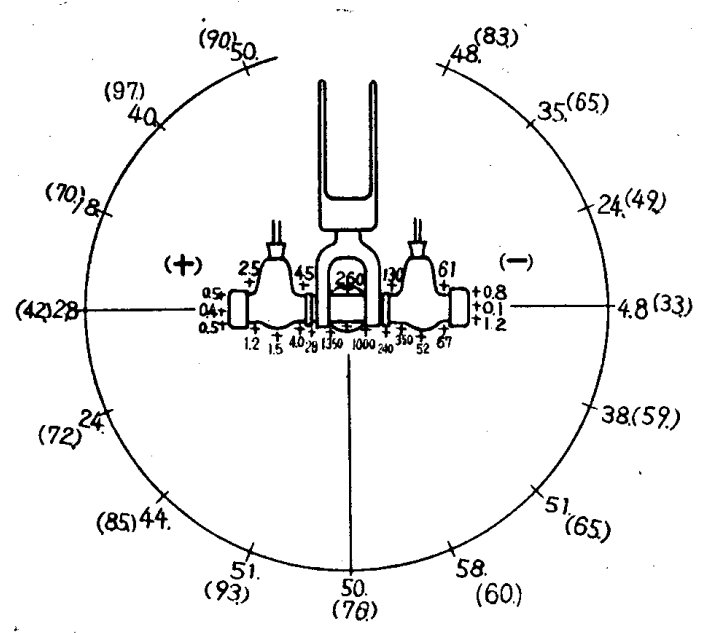

第 4 图 - 1

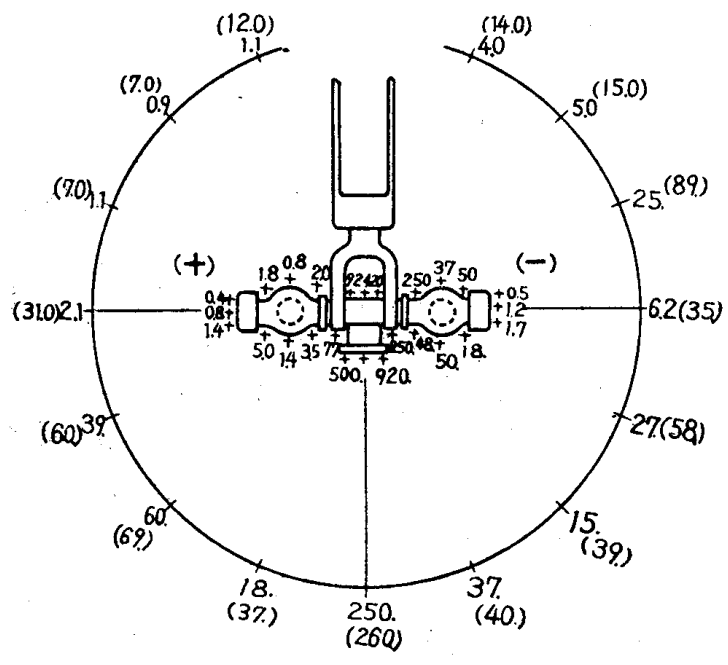

第 4 图 -2

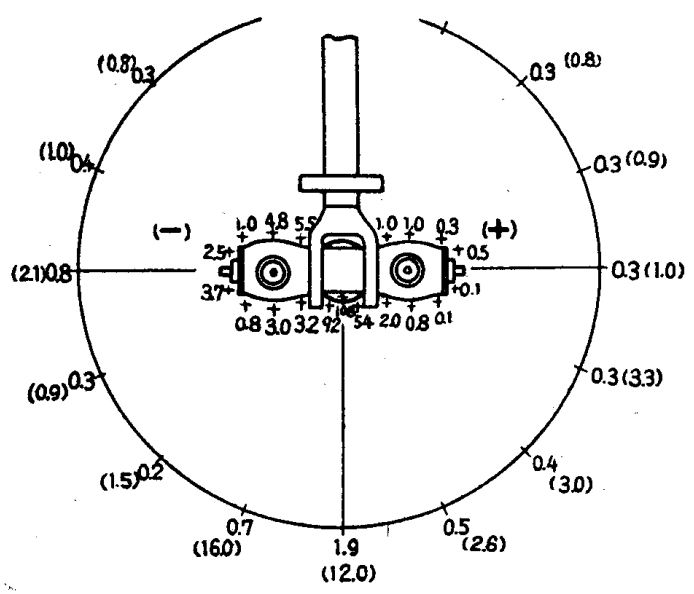

第 5 図 -1

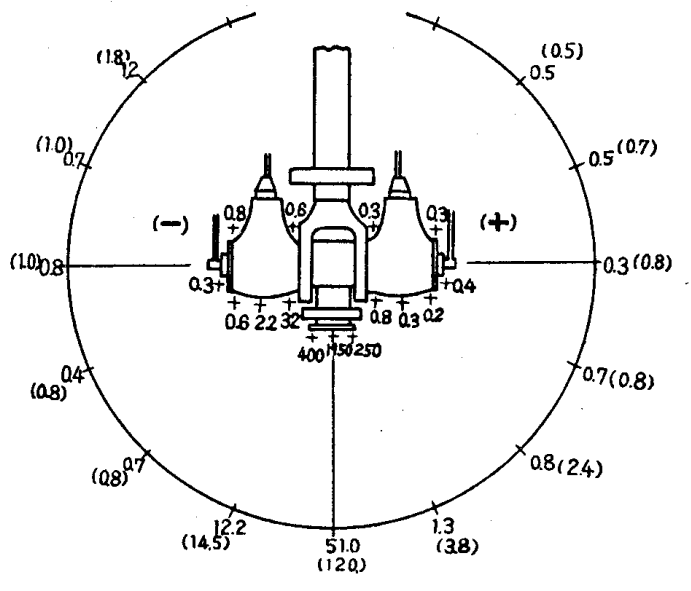

第 5 図 -2

表とも装置而の漏洩は多くなっていた，てれを図示すれ ば第 2 図から第 5 図のとおりである。

第 4 表の装置 I， II では漏洩量の少ない陽極側で半価 層は厚く、四では放射口部の陽極側に漏洩の多い部分が あるため, 半価㐿はほぼ等しくなっている、Nでは漏洩 が少なく测定できなかった。また，当然のととながら， 1 次線の半価層よりも I, IIの陽極側で約 1.7 2 倍, 陰極側では約 1.3〜1.5 倍, II では約 1.3 倍と厚くなつ ている。

第 4 表 瀮洩線の線質测定值

\begin{tabular}{|c|c|c|c|c|c|c|c|}
\hline \multirow[b]{2}{*}{ 装置 } & \multirow[b]{2}{*}{ 测定条件 } & \multicolumn{2}{|c|}{$\begin{array}{c}\text { 利用線錐 } \\
50 \mathrm{~cm}\end{array}$} & \multicolumn{4}{|c|}{ 瀮 洩 線 $50 \mathrm{~cm}$} \\
\hline & & $\begin{array}{l}\text { 線量 } \\
\text { r/分 }\end{array}$ & $\begin{array}{l}\text { H.V.L. } \\
\begin{array}{c}\mathrm{Cu} \\
(\mathrm{mm})\end{array}\end{array}$ & $\begin{array}{l}\mathrm{X}(\text { 陽做 } \\
\mathrm{mr} / \text { 時 }\end{array}$ & $\begin{array}{c}\left.\text { 側 } 45^{\circ}\right) \\
\text { H.V.L. } \\
\text { Cu } \\
(\mathrm{mm})\end{array}$ & $\mid \begin{array}{l}\mathrm{Y}(\text { 陰标 } \\
\mathrm{mr} / \text { 時 }\end{array}$ & $\begin{array}{c}\text { H.V.L. } \\
\text { Cu } \\
(\mathrm{mm}) \\
(\mathrm{mm})\end{array}$ \\
\hline I & $\begin{array}{c}200 \mathrm{kVp} \\
25 \mathrm{~mA}\end{array}$ & 52.0 & 1.78 & 8.7 & 3.03 & 22.0 & 2.35 \\
\hline $\mathbf{H}$ & $\begin{array}{c}200 \mathrm{kVp} \\
20 \mathrm{~mA}\end{array}$ & 53.5 & 1.52 & 4.7 & 3.37 & 7.3 & 2.36 \\
\hline H & $\begin{array}{c}180 \mathrm{kVp} \\
6 \mathrm{~mA}\end{array}$ & 12.36 & 1.42 & 350.0 & 1.84 & 80.0 & 1.85 \\
\hline N & $\begin{array}{r}180 \mathrm{kVp} \\
6 \mathrm{~mA}\end{array}$ & 13.6 & 1.20 & 1.6 & - & 2.2 & - \\
\hline
\end{tabular}

\section{V. 考按}

（1）漏洩量は一般的に陽極側より陰極側に多く，また， 小電流より大電流に著明である。これはすでに発表され た青木氏 ${ }^{5)}$ 等 $^{6)}$ の報告と同じ傾问を示している。

（2）シャッター閉鎖時のすり合せはいずれも不充分で あり, 装置 I はシャッターそのものの鉛当量が不足して いる.

（3）装置 I，】では漏洩線量の少ない陽極側で半価首 が増すことからも I，II 鉛当量は未だ不充分と思われ ろ. 
（4） 1953年 ICRP1) で造血蔵器の他に水晶体，生殖腺 についても考慮し，われわれの許容量を $0.3 \mathrm{r} / \mathrm{W}$ として いる. この值を基準に各容器の漏洩量の大きいもの 3 つ 宛について検討すると，装置 I の垂直方向では，77，55， $36 \mathrm{mr} / \mathrm{h}$ ゆ，われわれの 1 日の從労時間を 8 時間とす るなら代，管球焦点から $1 \mathrm{~m}$ の点で 5 〜 6 分，水平方问 の 350,440,420 $\mathrm{mr} / \mathrm{h}$ では 50 -60 秒, 装置 II. 水平方闾 の $65,50,38 \mathrm{mr} / \mathrm{h}$ の点では 7 10 分, 亚の垂直方向 97 , $90,85 \mathrm{mr} / \mathrm{h}$ では4 4.5分, 水平方向では $89,60,69 \mathrm{mr} / \mathrm{h}$ 4一6 分で $6.25 \mathrm{mr} / \mathrm{h}(=0.3 \mathrm{r} / \mathrm{W})$ の值をこえることにな る。しかもわれわれが実際作業する位置は焦点より $1 \mathrm{~m}$ 以内の点であり, 漏洩線の線質は第 4 表に示したように 非常に硬く，加量的にも $1 \mathrm{~m}$ の值よりはるかに大とな るから, シャッターを閉じているとの安易な考えで容器 に接近することは伦険である。

（5）鉛当量 $0.3 \mathrm{~mm}$ 程度の鉛ゴム製品では，かかる線 質の漏洩線に対してはせいぜい半減できるにすぎないて。

\section{VI. 結 論}

以上を総括すると

(1) X 線管容器の漏洩試験は JIS T-1104 の方法によ る相対的なものでなく絶対量で，また，試験電圧は 170 $\mathrm{kVp}$ でなく，最大使用電圧で規制されるべきである。

(2) X 線管容器製作のときには, 陰極側の防禦を特に
入念に.

(3) シャッター機構はより充分にその機能を発揮でき るように改善ずべきである。

(4) 高死を印加し，管電流を流したままの状態では， シャッターを閉しても管容器に接近することは避けるべ きで，万止むを得ないときには陽極側て操作すること。

（5）管容器を傾斜させて治療を打こなら場合，息者の 被曝線量を軽減するために，陰極側を遠ざけるような体 位をとらせることが必要と思われる。

報告を終るに際し，本実験に数々のご指導とご助言を いだたいた放射線科医局長宫村利雄先生に深謝の意を表 します。

\section{參 考 交献}

1）樋口助弘：放射能の人体最大許容量, 日放技誌, 第 14 巻 1,2 号, 1 定, 1958.

2) 国連科学委員会報告：科学朝日, 朝日新聞社, 1958 .

3）医療法施行規則，第四章，第二節，第28条.

4）日本工業標準調查会：JIS T-1104.

5）青木重秋：X線治療わよび放射性同位元素治療時の 散乱線防護, 日放技誌, 第12巻, 3,4 号, 9 頁, 1956.

6) 藤本䓌治: 工業X 線写真, 日刊工業新聞社, 1954.

7）三上徹吉他：ビニール製防護手套の鉛当量測定成績 について，日工技会誌，第 5 卷 1 号，1958.

\section{本 部 報告}

$\diamond 34$ 年 7 月 4 日 本部事務所において事務局, 運営, 編 集部の定例協議会を行いそれぞれ担当事務の処理を行 5 .

$\diamond 34$ 年 7 月 8 日 山中太郎先生御逝去され本会より, 金 子会長代理として川㱦常任幹事力御葬儀に参列して御 韦意を捧げ御冥福を祈りました。

$\diamond 34$ 年 8 月 1 日 本部事務所において事務局並編集部委 員会を開催し第十五巻一号誌の校正並び社団法人の手 続要項に関しそれぞれ協議を行う.

$\diamond 34$ 年 9 月 5 日 事務局, 編集部, 運営委の合同協議会 を開催し, 特輯四号アイソトープ基礎編発行準備及び
法人要項につき協議を行う。

$\diamond 34$ 年 9 月 7,8 日 第十五巻一号誌並び幹事委噣状発 送す。

$\diamond 34$ 年10月 3 日 本部事務所において編集部並び事務局 の定例協議会を開催し第十五巻二号誌発行準備を行い 例て特輯号校正を行引。

$\diamond 34$ 年10月 7 日 9 日 事咯局会議を行い法人手続に関し 京都府庁教育文化財保護課を訪問す。

$\diamond 34$ 年10月30, 31 日 事務局会議を行い法人手続上の内 容につき再検討をする。 